\title{
ANALISIS FAKTOR INFLASI BULANAN PROVINSI BANTEN 2011-2017
}

(Factor Analysis of Monthly Inflation in Banten Province, 2011-2017)

\author{
Euis Naya Sari \\ Pusdiklat Badan Pusat Statistik \\ Jl. Raya Jagakarsa No. 70, Lenteng Agung, Jakarta 12620 \\ Email: enayasari@gmail.com \\ Naskah diterima: 11 Desember 2018 \\ Naskah direvisi: 24 Januari 2019 \\ Naskah diterbitkan: 30 Juni 2019
}

\begin{abstract}
Understanding the changes of inflation rate in a specific region is very essential, in order for the local government to maintain the inflation and to issue policies when inflation instability occurs. Inflation rate is one of the important indicators that reflects the economic development of a region. Inflation rate is measured by involving several variables taken from various types of expenditures. This study therefore aims to analyze subgroup expenditure variables which play significant role in explaining the monthly inflation rate in Banten Province, by focusing on the Consumer Price Index of three major cities, i.e. Serang, Tangerang, and Cilegon, using literature studies supported by quantitative descriptive analysis Kaiser-Meyer-Olkin Test, Bartlett Test, and factor analysis. For the factor analysis, the monthly data series for the period of 2011-2017 (84 months) consisting of 35 subgroups of goods/services, each of which is formed by several commodities, is analyzed. The data is obtained from the prices of goods/services recorded in every week or month. The results showed that, based on the factor analysis, only 26 variables out of 35 subgroup variables can be grouped into 5 factors, the remaining subgroup variables cannot be included in any factor. These 26 variables can explain as much as 34 percent in the variation of the monthly inflation rate. Meanwhile, the other 66 percent is explained by other factors which are not included in the model. In addition, the study also concluded that the causes of inflation during the study period were demand-pull inflation and cost-push inflation.
\end{abstract}

Keywords: consumer price index, inflation, Banten Province

\begin{abstract}
Abstrak
Perkembangan tingkat perekonomian dipengaruhi oleh banyak faktor, salah satunya adalah inflasi. Sementara itu tingkat inflasi sendiri banyak dipengaruhi oleh beberapa variabel, seperti pengeluaran yang dikelompokkan menjadi berbagai subkelompok. Dengan demikian, pemahaman tentang perkembangan tingkat inflasi sangat penting untuk diketahui oleh pemerintah daerah agar dapat mempertahankan tingkat inflasi dan mengeluarkan kebijakan ketika terjadi masalah. Berkaitan dengan hal itu, penelitian ini bertujuan menganalisis variabel-variabel pengeluaran subkelompok yang berperan dalam menjelaskan tingkat inflasi bulanan di Provinsi Banten. Penelitian ini fokus pada data ekonomi Provinsi Banten tahun 2011-2017, terutama pada Indeks Harga Konsumen (IHK) dari tiga kota besar di Banten, yaitu Serang, Kota Tangerang, dan Kota Cilegon, dengan menggunakan kajian pustaka yang ditunjang dengan analisis deskriptif kuantitatif dan Uji KMO (Kaiser-Meyer-Olkin), Uji Bartlett, serta Analisis Faktor terhadap data sekunder. Dalam analisis faktor digunakan 5 faktor yang berasal dari data inflasi pada 35 subkelompok pengeluaran barang/jasa dengan data series bulanan tahun 2011-2017 (84 bulan). Masing-masing subkelompok terbentuk dari beberapa komoditas yang datanya berasal dari pencatatan harga barang/jasa di setiap minggu atau bulannya. Hasil kajian ini menunjukkan, berdasarkan hasil analisis faktor dari 35 variabel subkelompok yang dipilih, hanya 26 variabel yang dapat dikelompokkan ke dalam 5 faktor, sisanya tidak masuk dalam faktor manapun. Sebanyak 26 variabel tersebut dapat menjelaskan variasi tingkat inflasi bulanan di Provinsi Banten, yaitu sebesar 34 persen. Sisanya dijelaskan oleh faktor lain yang belum masuk di dalam model. Selain itu, dapat dijelaskan pula bahwa inflasi di Provinsi Banten selama periode penelitian disebabkan oleh demand-pull inflation dan cost-push inflation.

Kata kunci: indeks harga konsumen, inflasi, Provinsi Banten
\end{abstract}

\section{PENDAHULUAN}

Salah satu indikator ekonomi makro yang digunakan untuk melihat atau mengukur stabilitas perekonomian suatu negara adalah inflasi (Kalsum, 2017). Inflasi adalah kenaikan harga sejumlah barang dan jasa secara umum dalam periode tertentu Menurut Mishkin (2001) dalam Maggi \& Saraswati (2013) inflasi merupakan kecenderungan dari harga-harga untuk naik secara umum dan terus-menerus berkaitan dengan mekanisme pasar yang dapat disebabkan oleh beberapa faktor, di antaranya adalah peningkatan konsumsi masyarakat, peningkatan persediaan uang, maupun ketidaklancaran distribusi barang.
Hitungan di dalam perubahan harga terkait inflasi tercakup dalam suatu indeks harga yang dikenal dengan Indeks Harga Konsumen (IHK) atau Consumer Price Index (CPI). Indeks ini mengukur perubahan tingkat harga eceran barang dan jasa konsumsi rumah tangga dari waktu ke waktu. Oleh sebab itu, salah satu cara untuk menentukan peramalan nilai inflasi dapat dilakukan dengan meramalkan nilai IHK tersebut (Arini \& Bendesa, 2012). Lebih lanjut menurut (Tripena, 2011), IHK pun menjadi indikator yang umum digunakan untuk mengukur inflasi suatu negara, termasuk pengukuran inflasi yang terjadi di Indonesia. 
Selain digunakan sebagai salah satu ukuran kinerja perekonomian suatu negara, inflasi yang tinggi dan tidak stabil juga memiliki dampak negatif, baik terhadap bidang ekonomi, politik, dan sosial masyarakat. Hal ini menjadi pertimbangan penting mengapa inflasi perlu dikendalikan (Algifari, 2009). Bahkan apabila kondisi inflasi tersebut berlansung lama maka akan mengganggu stabilitas kehidupan suatu negara dan menyebabkan krisis ekonomi. Hal ini diperkuat oleh penelitian dari Ardiansyah (2017) di mana inflasi pada tingkat tertentu memang berpengaruh negatif terhadap pertumbuhan ekonomi.

Inflasi yang tinggi dapat menyebabkan pendapatan riil masyarakat menurun sehingga daya belinya juga akan menurun. Dampak berikutnya dapat dilihat dari penurunan standar hidup yang kemudian membuat banyak orang, terutama kelompok miskin, semakin bertambah miskin (Saputra \& S.B.M., 2014). Untuk mempermudah deteksi inflasi yang tinggi tersebut, secara umum inflasi digolongkan menjadi 4, yaitu inflasi ringan, sedang, berat, dan hiperinflasi. Inflasi dikatakan ringan apabila kenaikan harga berada di bawah 10 persen per tahun, inflasi tingkat sedang jika berada 10-30 persen per tahun, inflasi tingkat berat jika berada 30-100 persen per tahun, dan hiperinflasi atau inflasi tak terkendali jika kenaikan harganya di atas 100 persen per tahun (Atmaja, 1999).

Provinsi Banten menjadi salah satu provinsi yang memiliki tingkat inflasi relatif cukup tinggi dibandingkan inflasi di kota-kota di Pulau Jawa dan nasional. Lokasinya yang berdekatan dengan ibu kota negara ternyata tidak serta merta menjadikannya memiliki tingkat inflasi yang moderat. Misalnya kondisi tingkat inflasi tinggi terjadi pada kuartal III tahun 2017 dan banyak didorong oleh inflasi kelompok bahan bakar, penerangan, dan air (Bank Indonesia, 2017). Sebagai akibatnya, upah di Provinsi Banten menjadi tidak kompetitif dibandingkan wilayah lain di Pulau Jawa dan menyebabkan industri padat karya menjadi tidak berdaya saing.

Hal tersebut menunjukkan bahwa terjadinya inflasi di Banten dipengaruhi oleh banyak komponen atau kelompok komoditas. Untuk itu, penulis bertujuan mengelompokkan dan menganalisis variabel-variabel pengeluaran subkelompok yang berperan dalam menjelaskan tingkat inflasi di Provinsi Banten. Harapannya, kebijakan yang tepat dapat diambil untuk menekan laju inflasi di Provinsi Banten.

\section{METODE}

Penelitian ini menggunakan metode kajian pustaka yang didukung analisis deskriptif kuantitatif serta analisis inferensia. Khusus pada metode inferensia menggunakan analisis faktor, yaitu metode analisis multivariat yang didasarkan pada korelasi antarvariabel. Analisis faktor dipergunakan untuk mereduksi data atau meringkas, dari variabel lama yang banyak diubah menjadi sedikit variabel baru yang disebut faktor, dan masih memuat sebagian besar informasi yang terkandung dalam variabel asli (Supranto, 2004). Pendapat lain mengatakan jika analisis faktor digunakan untuk mengenali dimensi pokok atau keteraturan sebuah fenomena. Secara umum, analisis faktor dipergunakan dalam kondisi sebagai berikut:

1. mengenali atau mengidentifikasi dimensi yang mendasari (underlying dimensions) atau faktor yang menjelaskan korelasi antara suatu set variabel.

2. mengenali atau mengidentifikasi suatu set variabel baru yang tidak berkorelasi (independent) yang lebih sedikit jumlahnya untuk menggantikan suatu set variabel asli yang saling berkorelasi di dalam analisis multivariat selanjutnya.

3. mengenali atau mengidentifikasi suatu set variabel yang penting dari suatu set variabel yang lebih banyak jumlahnya untuk dipergunakan dalam analisis multivariat selanjutnya.

Pendekatan yang paling popular digunakan dalam analisis faktor adalah principal component analysis, yaitu analisis yang menstransformasikan sejumlah variabel ke dalam suatu variabel komposit baru, atau komponen utama yang tidak berkorelasi satu sama lain (Kuncoro, 2011).

Penelitian ini menggunakan data series inflasi bulan Provinsi Banten tahun 2011-2017 sebanyak 84 bulan yang diperoleh dari situs BPS Provinsi Banten. Data series atau data deret waktu merupakan data yang menggambarkan suatu kejadian dari waktu ke waktu atau periode yang saling berkorelasi (Aswi \& Sukarna, 2006). Adapun angka inflasi diuraikan menjadi 7 kelompok pengeluaran dan dijabarkan kembali menjadi 35 variabel subkelompok pengeluaran. Pada 35 variabel subkelompok pengeluaran barang/jasa yang diperoleh, masing masing subkelompok terbentuk dari beberapa komoditas yang datanya berasal dari pencatatan harga barang/jasa di setiap minggu atau bulannya melalui wawancara secara langsung (BPS, 2017a).

Penggunaan analisis faktor didasari oleh banyaknya kelompok pengeluaran yang berpengaruh terhadap inflasi. Kelompok pengeluaran ini dapat saling berkaitan antara satu kelompok dengan kelompok lainnya sehingga dengan menggunakan analisis faktor maka kelompok pengeluaran tersebut 
dapat direduksi menjadifaktor-faktor. Faktor tersebut selanjutnya dianalisis pengaruhnya terhadap inflasi. Analisis faktor juga dapat mengidentifikasi adanya hubungan antarkelompok pengeluaran dalam faktor yang sama. Analisis inferensia dilakukan dengan menggunakan software R (Pramana, 2015). Analisis faktor dalam penelitian ini mencakup beberapa uji (Johnson \& Wichern, 2002), yaitu:

1. Uji Bartlett (Bartlett Test of Sphericity)

$$
\mathrm{X}_{\text {obs }}=-[\mathrm{N}-1)-\frac{(2 \mathrm{p}+5)}{6}|\ln | \mathrm{R} \mid
$$

Di mana:

$\mathrm{N}$ : jumlah observasi.

$\mathrm{p}$ : jumlah variabel.

$\mathrm{R}$ : determinan dari matriks korelasi.

Statistik uji Bartlett digunakan untuk menentukan apakah reduksi dimensi variabel bermakna untuk dilakukan analisis komponen utama. Analisis multivariat dapat digunakan dengan menggunakan metode komponen utama dan analisis faktor saat $p$-value $<0,05$ (Gujarati, 2003). Setelah melakukan uji Bartlett, selanjutnya digunakan uji KMO.

2. Uji KMO (Kaiser-Meyer-Olkin)

$$
\mathrm{KMO}=\frac{\left[\Sigma \Sigma r_{i k}^{2}\right]}{\left[\Sigma \Sigma r_{i k}^{2}+\Sigma \Sigma \alpha_{i k}^{2}\right]}
$$

Di mana:

$r_{\mathrm{ik}}:$ koefisien korelasi sederhana antara variabel $i$ dan $k$.

$\alpha_{\mathrm{ik}}:$ koefisien korelasi parsial antara variabel $i$ dan $k$.

Statistik KMO digunakan untuk mengetahui apakah himpunan data layak dianalisis dengan analisis faktor. Jika nilai KMO yang dihasilkan kecil $(\leq 0,5)$ maka penggunaan analisis faktor harus dipertimbangkan kembali. Apabila nilai $\mathrm{KMO}>0,5$, maka dapat dilakukan analisis faktor pada data tersebut.

3. Analisis Faktor

Model Faktor:

$\mathrm{X}_{1}-\mu_{1}=\lambda_{11} \mathrm{~F}_{1}+\lambda_{12} \mathrm{~F}_{2}+\ldots+\lambda_{1 \mathrm{q}} \mathrm{F}_{\mathrm{q}}+\varepsilon_{1}$ $\mathrm{X}_{2}-\mu_{2}=\lambda_{21} \mathrm{~F}_{1}+\lambda_{22} \mathrm{~F}_{2}+\ldots+\lambda_{2 \mathrm{q}} \mathrm{F}_{\mathrm{q}}+\varepsilon_{2}$

$\vdots$

$\mathrm{X}_{\mathrm{p}}-\mu_{\mathrm{p}}=\lambda_{\mathrm{p} 1} \mathrm{~F}_{1}+\lambda_{\mathrm{p} 2} \mathrm{~F}_{2}+\ldots+\lambda_{\mathrm{pq}} \mathrm{F}_{\mathrm{q}}+\varepsilon_{\mathrm{p}}$ atau dalam notasi matriks dituliskan sebagai berikut:

$X_{(p \times 1)}=\mu_{(p \times 1)}+L_{(p \times m)}+F_{(m \times 1)}+\varepsilon_{(p \times 1)}$

Di mana:

$$
\begin{aligned}
\mathrm{X}_{(\mathrm{p} \times 1)}: & \text { vektor variabel independen dengan } \\
& p \text { komponen. }
\end{aligned}
$$

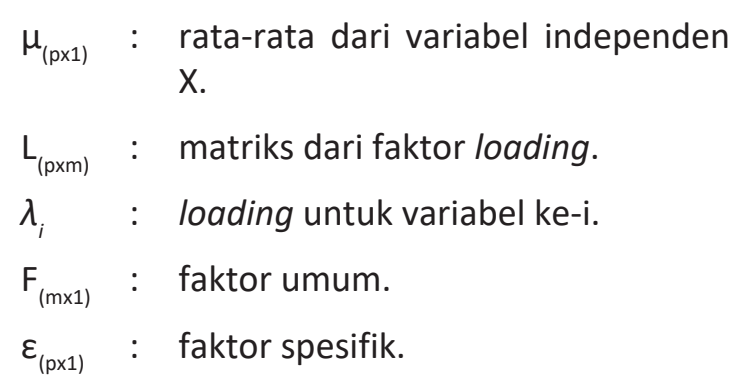

\section{HASIL DAN PEMBAHASAN}

Perkembangan Inflasi Provinsi Banten Tahun 2017

Inflasi merupakan kencenderungan kenaikan harga secara umum dan terus-menerus dalam jangka waktu tertentu (Daniel, 2018). Selama kurun waktu tahun 2011-2017 perkembangan tingkat inflasi di Provinsi Banten mengalami fluktuasi. Hal ini diketahui berdasarkan pemantauan yang dilakukan oleh BPS terhadap 417 jenis barang dan jasa serta hasil Survei Biaya Hidup (SBH) tahun 2012 yang dilakukan di tiga kota besar kota inflasi, yaitu Kota Serang, Tangerang, dan Cilegon, baik secara mingguan, dua mingguan, maupun bulanan. Dari hasil pemantauan tersebut diperoleh informasi bahwa pada Desember 2017 terdapat 216 komoditas mengalami perubahan harga. Rincian sebanyak 141 komoditas mengalami kenaikan harga dan sisanya sebanyak 75 komoditas mengalami penurunan harga dapat dilihat pada Gambar 1.

Secara umum, inflasi bulanan di Provinsi Banten selama tahun 2017 (0,02-0,71 persen) tercatat mengalami peningkatan dibandingkan bulan-bulan sebelumnya, kecuali pada Agustus dan Oktober mengalami penurunan, yaitu sebesar $-0,01$ persen (Agustus), dan 0,02 persen (Oktober). Angka inflasi Januari 2017 adalah sebesar 0,71 persen lebih rendah dibandingkan inflasi Desember 2016 yang mencapai 0,88 persen, sedangkan pada Desember 2017 angka inflasi di Banten sebesar 0,70 persen. Tercatat kelompok komoditas yang memberikan andil/sumbangan terhadap inflasi di Provinsi Banten, yaitu kelompok bahan makanan sebesar 0,399 persen; kelompok transportasi, komunikasi dan jasa keuangan sebesar 0,204 persen; kelompok makanan jadi, minuman, rokok dan tembakau sebesar 0,123 persen; kelompok kesehatan sebesar 0,005 persen; kelompok pendidikan, rekreasi dan olahraga sebesar 0,001 persen; kelompok sandang sebesar -0,007 persen; serta kelompok perumahan, air, listrik, gas dan bahan bakar sebesar $-0,027$ persen.

Tingginya inflasi pada kelompok bahan makanan karena beberapa komoditas pada kelompok bahan makanan tersebut memiliki sifat mudah rusak (perishable). Akhir tahun yang merupakan musim penghujan, semakin memperparah kerusakan yang 


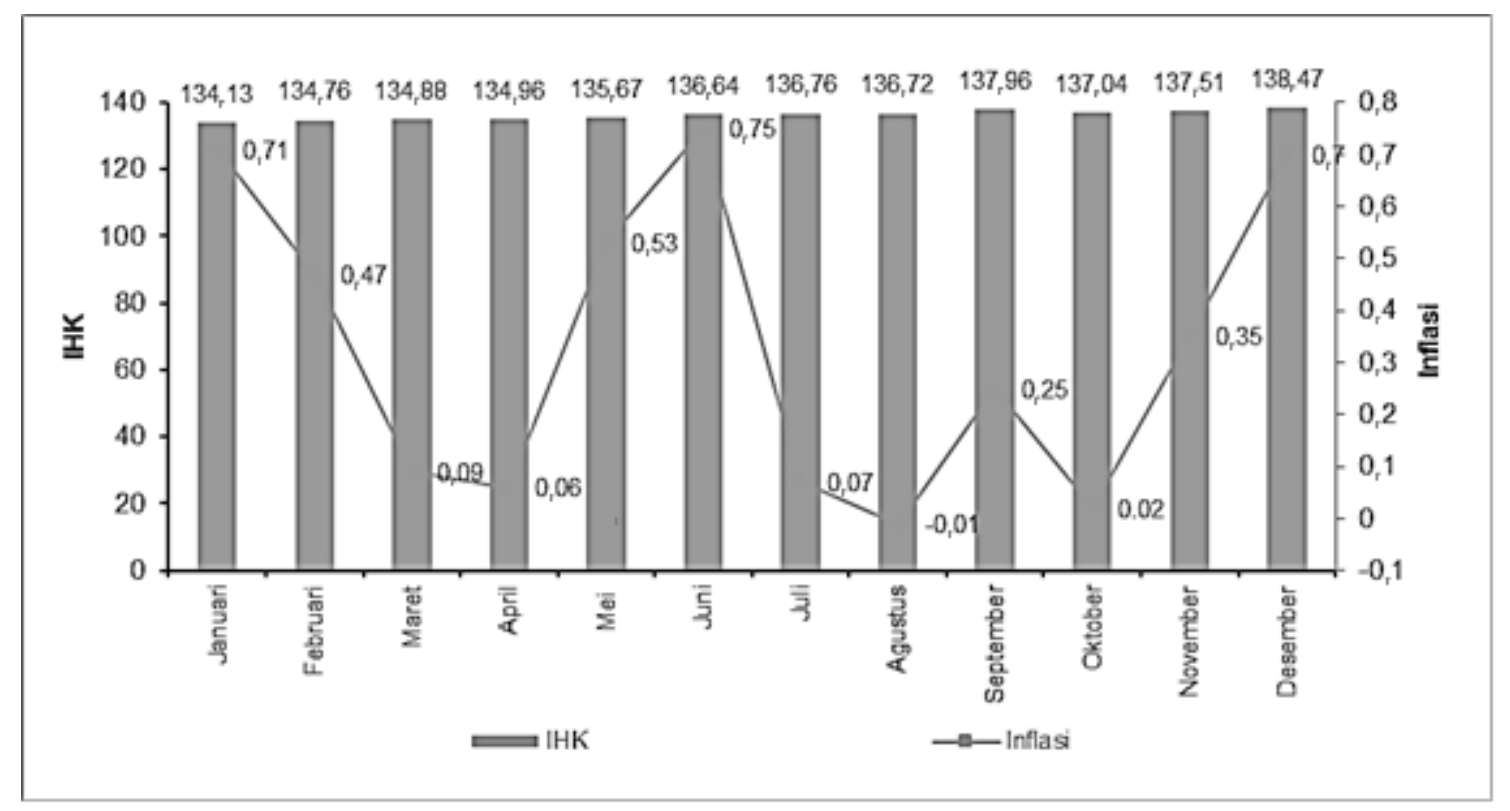

Sumber: BPS Provinsi Banten (2017).

Gambar 1. Perkembangan IHK dan Inflasi Bulanan di Provinsi Banten Tahun 2017

terjadi. Sebagai akibatnya, suplai komoditas tersebut berkurang dan mengakibatkan meningkatnya harga. Sedangkan inflasi pada kelompok transportasi, komunikasi, dan jasa keuangan disebabkan tingginya permintaan masyarakat terhadap angkutan udara (Bank Indonesia, 2017). Pada triwulan IV tahun 2017, terjadi peningkatan jumlah penumpang pesawat dikarenakan musim liburan yang jatuh pada Desember. BPS mencatat bahwa jumlah penumpang pesawat untuk rute domestik pada triwulan IV tahun 2017 tumbuh 10,09 persen dibandingkan triwulan IV pada tahun 2016. Adapun inflasi pada komunikasi disebabkan karena penyesuaian harga yang dilakukan oleh provider dan kebijakan pemerintah terkait biaya interkoneksi antar-provider sehingga memengaruhi pengguna layanan komunikasi di Provinsi Banten yang lebih banyak menggunakan layanan telepon (Bank Indonesia, 2017).

\section{Hasil Uji KMO dan Bartlett serta Analisis Faktor}

Analisis faktor dalam penelitian ini menggunakan metode Kaiser-Meiyer-Olkin (KMO). Uji KMO ini dilakukan untuk mengetahui apakah faktor-faktor dalam peneltian valid atau tidak. Menurut Gozali (2013), angka KMO dan Bartlett's Test harus di atas 0,5 dan signifikansi harus berada di bawah 0,05. Selanjutnya untuk melihat korelasi antarvariabel independen dapat dilihat pada Tabel Anti-Image Matrices. Nilai yang diperhatikan adalah Measure of Sampling Adequacy (MSA). Nilai MSA tersebut berkisar antara 0 hingga 1, dengan ketentuan sebagai berikut (Santoso, 2006):

1. $\mathrm{MSA}=1$ artinya variabel dapat diprediksi tanpa kesalahan oleh variabel lain.
2. MSA $>0,5$ artinya variabel masih bisa diprediksi dan bisa dianalisis lebih lanjut.

3. $M S A<0,5$ artinya variabel tidak bisa diprediksi dan tidak bisa dianalisis lebih lanjut atau dikeluarkan dari variabel lainnya.

Berdasarkan ketentuan tersebut, hasil perhitungan pada penelitian ini diperoleh nilai Bartlett's K-squared $=3758,611, \mathrm{df}=34, \mathrm{p}$-value $<$ 2,2e-16, nilai KMO sebesar 0,55 sehingga $\mathrm{KMO}>$ 0,5 , dan nilai $p$-value dari uji Bartlett $<0,05$. Melalui hasil MSA maka seluruh variabel independen dapat dianalisis lebih lanjut karena masing-masing nilainya $>0,5$. Sedangkan dari kedua uji tersebut maka metode analisis faktor dapat digunakan dalam penelitian ini. Dan berdasarkan hasil penghitungan yang diperoleh sebelumnya, variabel dan sampel yang digunakan masih memungkinkan untuk dilakukan analisis lebih lanjut.

Selanjutnya untuk melihat variabel-variabel mana saja yang layak untuk dibuat analisis faktor serta untuk mengetahui penentuan jumlah faktor atau variabel laten yang akan dibuat sebagai faktor analisis yang mempunyai korelasi kuat atau tidak dengan nilai lebih besar atau sama dengan 0,5. Jika nilainya lebih besar atau sama dengan 0,5 maka semua faktor pembentuk variabel tersebut telah valid dan tidak ada faktor yang akan direduksi. Pada Gambar 2 disajikan hasil pengolahan yang dilakukan dengan menggunakan uji KMO dan Bartlett dalam penentuan jumlah faktor/variabel laten yang akan dibuat dengan menggunakan scree plot.

Scree plot merupakan salah satu cara untuk menunjukkan berapa faktor yang diperlukan agar diperoleh hasil yang optimal. Scree plot terdiri 
Tabel 1. Uji KMO dan Bartlett

Overall MSA $=0.55$

MSA for each item =

\begin{tabular}{|c|c|c|c|c|c|}
\hline No. & MSA & No. & MSA & No. & MSA \\
\hline 1. & 0,77 & 11. & 0,43 & 21. & 0,71 \\
\hline 2. & 0,46 & 12. & 0,64 & 22. & 0,58 \\
\hline 3. & 0,50 & 13. & 0,35 & 23. & 0,67 \\
\hline 4. & 0,49 & 14. & 0,63 & 24. & 0,37 \\
\hline 5. & 0,29 & 15 & 0,66 & 25. & 0,44 \\
\hline 6. & 0,40 & 16. & 0,62 & 26. & 0,41 \\
\hline 7. & 0,31 & 17. & 0,57 & 27. & 0,66 \\
\hline 8. & 0,47 & 18. & 0,36 & 28. & 0,61 \\
\hline 9. & 0,52 & 19. & 0,80 & 29. & 0,42 \\
\hline 10. & 0,36 & 20. & 0,64 & 30. & 0,73 \\
\hline
\end{tabular}

\begin{tabular}{ll}
\hline No. & \multicolumn{1}{c}{ MSA } \\
\hline 31. & 0,48 \\
\hline 32. & 0,54 \\
\hline 33. & 0,54 \\
\hline 34. & 0,45 \\
\hline 35. & 0,33 \\
\hline
\end{tabular}

Keterangan: Bartlett's K-squared $=3758,611 ; \mathrm{df}=34 ; \mathrm{p}$-value $<2,2 \mathrm{e}-16$.

Sumber: Hasil olah data inflasi (UNECE, et al., 2009 dan Pramana, 2015).

dari nilai eigen pada sumbu $y$ dan jumlah faktor pada sumbu $x$. Scree plot selalu membentuk kurva menurun. Untuk menentukan berapa faktor yang optimal maka dilihat titik di mana kurva mulai menunjukkan penurunan yang landai.

Seperti yang terlihat dari scree plot terlihat bahwa untuk hasil yang optimal, diperoleh jumlah faktor adalah 5. Penentuan faktor dari variabel adalah dengan melihat nilai loading matrix terbesar $(>0,5)$ antara tiap variabel dengan faktor. Contohnya pada variabel 1 , nilai terbesar terletak pada faktor ke 2 (ML2), artinya variabel 1 (padi-padian, umbiumbian, dan hasilnya) masuk pada faktor ke 1 (Tabel 2). Kemudian, untuk variabel 2 , nilai terbesar terletak pada faktor ke 4. Sehingga, variabel 2 masuk ke dalam faktor ke 4.
Tabel 3 menunjukkan variasi yang dapat dijelaskan oleh variabel dalam model. Hasil perhitungan tersebut menjelaskan bahwa faktor 1 mampu menjelaskan variansi dari 35 variabel sebesar 5 persen, faktor 2 sebesar 11 persen, faktor 3 sebesar 7 persen, faktor 4 sebesar 7 persen, dan faktor 5 sebesar 4 persen.

Dari hasil penghitungan tersebut maka pengelompokkan faktor-faktornya adalah sebagai berikut:

Faktor 1, terdapat 2 subkelompok pengeluaran:

1. sarana dan penunjang transportasi

2. komunikasi dan pengiriman

Faktor 2, terdapat 10 subkelompok pengeluaran:

1. sandang laki-laki

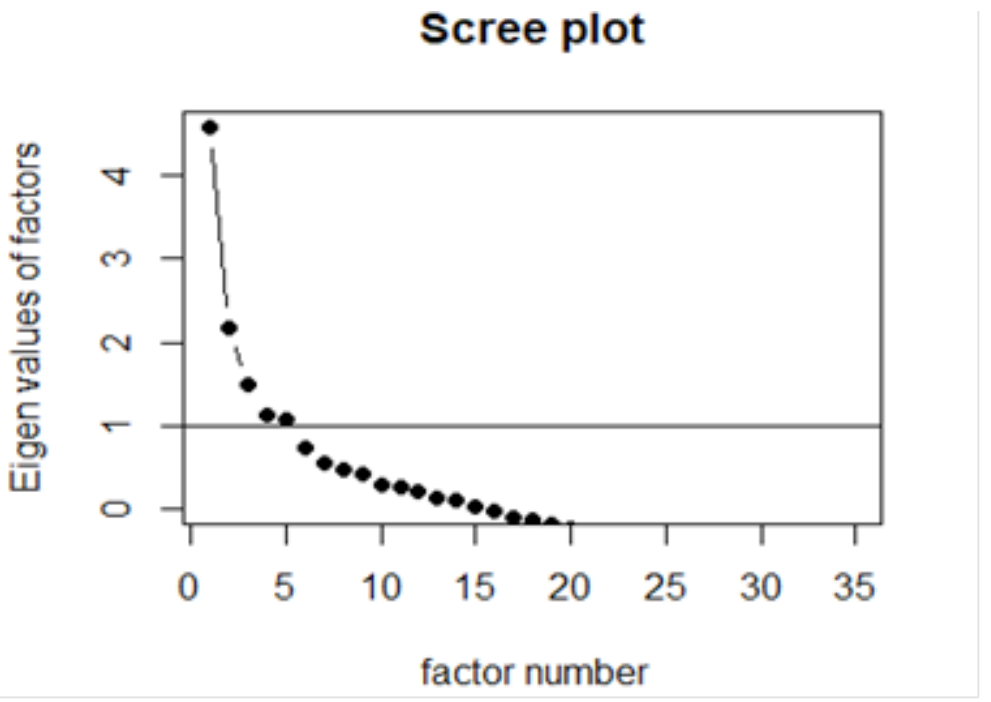

Sumber: Hasil olah data.

Gambar 2. Scree Plot Penentuan Jumlah Faktor 
Tabel 2. Loading Matrix

\begin{tabular}{|c|c|c|c|c|c|c|c|c|}
\hline No. & ML2 & ML3 & ML4 & ML1 & ML5 & h2 & u2 & com \\
\hline 1. & 0,70 & 0,21 & 0,01 & 0,20 & 0,10 & 0,577 & 0,423 & 1,4 \\
\hline 2. & 0,15 & 0,05 & 0,62 & $-0,04$ & $-0,11$ & 0,426 & 0,574 & 1,2 \\
\hline 3. & 0,29 & 0,00 & 0,28 & 0,25 & $-0,03$ & 0,228 & 0,772 & 3,0 \\
\hline$\ldots$ & $\ldots$ & $\ldots$ & $\ldots$ & $\ldots$ & $\ldots$ & $\ldots$ & $\ldots$ & $\ldots$ \\
\hline$\ldots$ & $\ldots$ & $\ldots$ & $\ldots$ & $\ldots$ & $\ldots$ & $\ldots$ & $\ldots$ & $\ldots$ \\
\hline$\ldots$ & $\ldots$ & $\ldots$ & $\ldots$ & $\ldots$ & $\ldots$ & $\ldots$ & $\ldots$ & $\ldots$ \\
\hline 82. & $-0,42$ & $-0,15$ & 0,11 & 0,53 & $-0,13$ & 0,509 & 0,491 & 2,3 \\
\hline 83. & 0,13 & 0,12 & $-0,02$ & 0,98 & 0,01 & 0,995 & 0,005 & 1,1 \\
\hline 84. & $-0,04$ & $-0,03$ & 0,12 & $-0,04$ & 0,08 & 0,025 & 0,975 & 2,4 \\
\hline
\end{tabular}

Keterangan:

ML1 : Faktor ke 1.

ML2 : Faktor ke 2.

ML3 : Faktor ke 3.

ML4 : Faktor ke 4.

ML5 : Faktor ke 5.

h2 : komunalitas.

u2 : variasi spesifik.

com : kompleksitas komponen loading.

Sumber : Hasil olah data inflasi (UNECE, et al, 2009 dan Pramana, 2015).

2. padi-padian, umbi-umbian dan hasilnya

3. barang pribadi dan sandang lain

4. sandang anak-anak

5. tembakau dan minuman beralkohol

6. jasa pendidikan

7. biaya tempat tinggal

8. ikan diawetkan

9. rekreasi

10. perlengkapan rumah tangga

Faktor 3, terdapat 4 subkelompok pengeluaran:

1. kursus-kursus/pelatihan

2. jasa kesehatan

3. olah raga

4. jasa perawatan jasmani

Faktor 4, terdapat 7 subkelompok pengeluaran:

1. daging dan hasil-hasilnya

2. transpor

Tabel 3. Variasi yang Dapat Dijelaskan Dalam Model

\begin{tabular}{ll}
\hline Faktor ke- & $\begin{array}{l}\text { Proporsi Variasi Variasi yang Dijelaskan } \\
\text { Masing-Masing Faktor }\end{array}$ \\
\hline Faktor 1 & 0,05 \\
\hline Faktor 2 & 0,11 \\
\hline Faktor 3 & 0,07 \\
\hline Faktor 4 & 0,07 \\
\hline Faktor 5 & 0,04 \\
\hline
\end{tabular}

Sumber: Hasil olah data inflasi (UNECE, et al., 2009 dan Pramana, 2015).
3. telur, susu, dan hasil-hasilnya

4. bumbu-bumbuan

5. sandang wanita

6. bahan bakar, penerangan, dan air

7. sayur-sayuran

Faktor 5, terdapat 3 subkelompok pengeluaran:

1. perlengkapan/peralatan pendidikan

2. makanan jadi

3. obat-obatan

Terdapat 9 subkelompok pengeluaran yang tidak tergolongkan dalam faktor, yaitu:

1. ikan segar

2. bahan makanan lainnya

3. lemak dan minyak

4. buah-buahan

5. minuman yang tidak beralkohol

6. kacang-kacangan

7. jasa keuangan

8. penyelenggaraan rumah tangga

9. perawatan jasmani dan kosmetika

Berdasarkan hasil analisis faktor eksploratori yang telah dilakukan terhadap 35 variabel/ subkelompok pengeluaran tersebut, terdapat 5 faktor yang mengelompokkan 26 dari 35 variabel/ subkelompok, dan sisanya tidak tergolongkan dalam faktor. Sesuai dengan kegunaan analisis faktor eksploratori, anggota/variabel dari masing-masing faktor yang terbentuk ini memiliki hubungan korelasi dengan sesama anggota faktor di dalamnya, namun 
tidak memiliki hubungan korelasi dengan anggota/ variabel di faktor lain. Hal ini berarti ada kemiripan karakteristik variabel pada satu faktor yang sama.

Sebagai contoh, faktor 3 yang terdiri dari kursuskursus/pelatihan, jasa kesehatan, olahraga, dan jasa perawatan jasmani memiliki karakteristik yang sama, yaitu kelompok pengeluaran untuk menjaga kesehatan jasmani. Sementara itu, faktor 4 yang terdiri dari daging dan hasil-hasilnya; transportasi; telur, susu, dan hasil-hasilnya; bumbu-bumbuan; sandang wanita; bahan bakar, penerangan, dan air; serta sayur-sayuran memiliki karakteristik yang sama, yaitu kelompok pengeluaran terkait kebutuhan pangan dan sandang. Kelompok pengeluaran pada faktor 3 dan 4 masing-masing memiliki karakteristik yang sama dalam satu faktor. Namun, kelompok pengeluaran pada faktor 4 tersebut tidak memiliki kaitan dengan kelompok pengeluaran pada faktor 3 .

Dari 35 variabel subkelompok pengeluaran yang dimasukkan ke dalam penelitian ini, 26 variabel yang masuk dalam 5 faktor mampu menjelaskan variasi besarnya inflasi bulanan di Provinsi Banten periode tahun 2011-2017 sebesar 34 persen sedangkan sisanya dijelaskan oleh faktor lain yang belum masuk di dalam model, misalnya suku bunga dan jumlah uang beredar (Fry, 1980). Untuk masing-masing faktor, faktor 1 menyumbang peranan 5 persen dalam variasi besarnya inflasi bulanan di Provinsi Banten, faktor 2 menyumbang peranan terbesar dari 5 faktor yang terbentuk, yaitu 11 persen, faktor 3 dan faktor 4 menyumbang peranan yang sama besar yaitu masing-masing sebesar 7 persen, dan terakhir faktor 5 menyumbang 4 persen terhadap variasi inflasi.

Faktor 1 terdiri dari 2 subkelompok pengeluaran, yaitu subkelompok pengeluaran sarana dan penunjang transpor dan subkelompok komunikasi dan pengiriman. Pada penelitian ini, faktor 1 ini berkontribusi sebesar 5 persen dalam variasi besarnya inflasi bulanan yang terjadi di Provinsi Banten periode tahun 2011-2017. Dari kedua anggota faktor ini dapat dilihat bahwa adanya kemiripan yaitu dalam hal distribusi barang dan jasa, yaitu dari segi transportasi dan pengiriman barang.

Faktor ini mewakili penjelasan yang telah diuraikan pada pendahuluan bahwa inflasi dapat juga disebabkan oleh desakan (tekanan) produksi dan/ distribusi atau kurangnya produksi termasuk juga kurangnya distribusi. Oleh karena itu, pengeluaran yang dilakukan untuk distribusi barang dan jasa ke suatu wilayah dapat memengaruhi harga barang itu sendiri di wilayah tersebut sehingga memungkinkan akan timbul inflasi di wilayah tersebut. Semakin tinggi biaya yang dikeluarkan untuk pengiriman dan distribusi suatu barang ke suatu daerah maka makin tinggi harga barang itu di daerah tersebut (Utari, et al., 2016).

Sedangkan, subkelompok komunikasi memengaruhi inflasi diduga disebabkan oleh adanya peningkatan penggunaan smartphone oleh masyarakat. Selain itu, inflasi pada komoditas komunikasi dapat disebabkan karena kebijakan provider telekomunikasi terkait harga pasca investasi yang bertujuan untuk meningkatkan daya saing provider tersebut. Kebijakan pemerintah yang berhubungan dengan interkoneksi antar provider juga dapat memengaruhi keputusan provider untuk melakukan penyesuaian harga. Hal ini disebabkan karena layanan provider di Provinsi Banten didominasi oleh layanan telepon (Bank Indonesia, 2017). Berdasarkan kajian ekonomi dan keuangan regional Provinsi Banten yang diterbitkan oleh Bank Indonesia tahun 2017, penyesuaian harga provider tersebut terjadi di beberapa kota di Banten, yaitu Tangerang Raya yang mencakup Kabupaten Tangerang, Kota Tangerang, dan Kota Tangerang Selatan.

Dari 10 subkelompok pengeluaran yang tergabung dalam faktor 2 dapat dilihat hubungan korelasi yang dimiliki antara satu dengan yang lainnya. Hubungan yang dapat diambil dari variabelvariabel yang masuk pada faktor 2 adalah variabelvariabel tersebut merupakan pengeluaran dari subkelompok barang yang termasuk kebutuhan primer, yaitu sandang (pakaian), pangan (makanan), dan papan (rumah/tempat tinggal).

Pada penelitian ini, faktor 2 yang berisikan variabel pengeluaran barang-barang kebutuhan primer menyumbang peranan terbesar dalam variasi tingkat inflasi bulanan yang terjadi di Provinsi Banten selama periode tahun 2011-2017, yaitu sebesar 11 persen. Hal ini berarti terjadinya perubahan-perubahan pada harga barang-barang primer yang tercakup dalam faktor ini akan memicu terjadinya inflasi. Hal ini sesuai dengan teori yang telah dijelaskan pada pendahuluan bahwa inflasi merupakan persentase kenaikan harga barang-barang dan jasa-jasa yang secara umum dikonsumsi rumah tangga. Oleh karena itu, faktor 2 yang berisikan barang dan jasa yang secara umum dikonsumsi rumah tangga, mampu menjelaskan variasi tingkat inflasi sebesar 11 persen yang merupakan nilai paling besar dibandingkan peranan faktor lain dalam beragamnya tingkat inflasi bulanan di Provinsi Banten pada periode penelitian.

Beberapa komoditas dalam faktor 2 tergolong sebagai volatile food. Inflasi volatile food atau inflasi komponen bergejolak adalah inflasi yang didominasi oleh gejolak yang terjadi pada kelompok bahan makanan, contohnya: panen, gangguan alam, atau perkembangan harga komoditas tersebut baik harga domestik maupun harga internasional 
(Bank Indonesia, 2018). Komoditas hortikultura, misalnya bawang yang termasuk umbi-umbian dan tercakup dalam faktor 2, memiliki sifat mudah rusak terutama saat musim hujan. Hal ini mengakibatkan berkurangnya ketersediaan komoditas tersebut di pasaran yang kemudian akan berpengaruh terhadap harga komoditas.

Selain itu, harga-harga barang primer yang dikonsumsi secara umum dan meluas di masyarakat mampu menggerakkan angka inflasi. Hal ini disebabkan karena kebutuhan akan barang-barang tersebut akan tetap selalu ada (dengan asumsi kondisi lain tetap/ceteris paribus) meskipun kondisi penawaran barang tersebut di pasar sedang tidak mencukupi. Kondisi ini akan terus mendorong permintaan akan barang tersebut namun dengan jumlah yang terbatas maka harga barang tersebut akan naik (Sukirno, 2008).

Selanjutnya, untuk periode waktu tertentu harga barang tersebut akan terus naik dan menyebabkan ketidakseimbangan di pasar. Kondisi ini akan mendorong harga-harga barang lainnya berubah seperti harga barang substitusi dan harga barang komplementer dari barang-barang yang mengalami kenaikan harga tersebut. Oleh sebab itu, inflasi dianggap terjadi jika proses kenaikan harga berlangsung secara terus menerus dan saling pengaruh dan memengaruhi (seperti yang telah dijelaskan di pendahuluan).

Banyak faktor yang turut memengaruhi perubahan pada tingkat inflasi. Secara garis besar perubahan tersebut dibagi menjadi dua bagian, yaitu tarikan permintaan atau demand pull inflation dan desakan biaya atau cost push inflation (Panjaitan \& Wardoyo, 2016). Inflasi ini biasanya diawali dengan inflasi jenis demand-pull inflation yang berarti dimulai dari terjadinya tarikan permintaan. Tarikan permintaan ini, berdasarkan teori kuantitas dalam teori inflasi, terjadi akibat tingginya permintaan akan barang dan jasa yang tidak diimbangi dengan ketersediaan barang dan jasa tersebut di pasaran.

Sebagai contoh, ketika tahun ajaran baru, permintaan akan perlengkapan sekolah akan semakin meningkat. Demand-pull inflation ini juga dapat terjadi ketika kondisi perekonomian sedang berkembang pesat dimana tingkat kesempatan kerja tinggi sehingga semakin banyak penduduk yang bekerja. Dengan kata lain, tingkat pengangguran menurun dan tingkat pendapatan masyarakat meningkat. Hal ini akan mendorong meningkatnya permintaan terhadap barang-barang kebutuhan rumah tangga yang melebihi kemampuan produsen dalam menyediakan kuantitas penawaran barang tersebut. Dengan kata lain, demand-pull inflation ini terkait dengan jumlah uang beredar yang meningkat di masyarakat yang akan mendorong tingkat permintaan akan barang dan jasa sehingga menyebabkan harga barang kebutuhan rumah tangga dan jasa meningkat.

Selanjutnya, faktor 3 menyumbang peranan 7 persen dalam menjelaskan variasi tingkat inflasi bulanan di Provinsi Banten pada periode penelitian. Subkelompok pengeluaran yang termasuk dalam faktor 3 dapat dilihat sebagai pengeluaran masyarakat untuk mendapat barang dan jasa kebutuhan sekunder seperti kursus/pelatihan, jasa kesehatan, olahraga, dan jasa perawatan jasmani yang merupakan kebutuhan lanjutan setelah terpenuhinya kebutuhan utama/primer masyarakat.

Banten merupakan provinsi yang bersebelahan dengan Provinsi DKI Jakarta serta pusat ibu kota Indonesia. Akibatnya, imbas pembangunan yang terjadi di ibu kota juga dirasakan oleh Provinsi Banten, termasuk bergesernya gaya hidup masyarakat. Kondisi dan kebutuhan gaya hidup yang menyesuaikan dengan tuntutan zaman membuat kebutuhan-kebutuhan sekunder ini menjadi hal yang penting untuk dipenuhi sehingga permintaan akan kebutuhan sekunder tersebut akan meningkat. Misalnya saja, anak sekolah yang memang harus bersaing dengan anak sekolah dari tempat lain yang lebih unggul. Anak tersebut akan mengikuti kursus tambahan seperti bimbingan belajar agar tidak tertinggal dari anak-anak lainnya. Keberadaan sarana dan prasarana kursus yang tersedia juga mendukung hal ini yang bisa dilihat dari banyaknya bimbingan belajar yang ada di Provinsi Banten. Kursus ini juga tidak terbatas pada pelajaran di sekolah, namun juga kursus bakat seperti alat musik dan menyanyi.

Hal yang sama juga dapat dilihat dari adanya sarana prasarana jasa perawatan jasmani, seperti klinik kecantikan dan sasana olahraga. Akibat dari meningkatnya pendapatan masyarakat, jasa perawatan jasmani menjadi kebutuhan primer yang harus dipenuhi seiring dengan perkembangan zaman. Hal ini tidak terlepas dari pembangunan yang merambat ke Provinsi Banten sebagai tetangga dari ibu kota negara.

Kebutuhan-kebutuhan sekunder ini mampu memengaruhi besarnya inflasi di Provinsi Banten selama periode tahun 2011 hingga tahun 2017 karena peranannya yang sudah mulai bergeser menjadi kebutuhan primer. Selain itu, beberapa pelayanan jasa-jasa ini juga membutuhkan alat dan bahan yang diimpor. Impor akan menyebabkan meningkatnya permintaan akan mata uang negara lain sehingga dapat menstimulasi nilai tukar Rupiah melemah.

Adanya depresiasi terhadap nilai tukar Rupiah dapat menyebabkan turunnya nilai riil Rupiah sehingga terjadi peningkatan biaya produksi. Sebagai 
akibatnya, nilai barang dan jasa yang dihasilkan juga akan meningkat. Dampak dari peningkatan biaya produksi yang digunakan untuk menghasilkan komoditas menyebabkan harga jualnya menjadi relatif tinggi. Sementara itu, di sisi lain tingkat pendapatan masyarakat relatif tetap (Harjunata, et al., 2016). Namun demikian, kendati harga barang mengalami peningkatan, masyarakat akan tetap berusaha untuk memenuhi kebutuhan-kebutuhan sekunder ini.

Faktor 4 ini mampu menjelaskan 7 persen dari keberagaman tingkat inflasi bulanan yang terjadi di Provinsi Banten. Faktor 4 terdiri dari pengeluaran subkelompok barang-barang hasil olahan industri maupun hasil produk pertanian dan peternakan, dan pengeluaran subkelompok barang-barang yang diperlukan dalam proses menghasilkan dan mengolahnya. Inflasi merupakan suatu keadaan di mana terjadi kelebihan suatu permintaan atas barang-barang di dalam suatu perekonomian secara menyeluruh (Haryani \& Priantinah, 2018).

Sebagai contoh adalah kenaikan harga daging yang mampu menaikkan harga barang-barang lain yang menggunakan bahan baku daging yang akan menyebabkan inflasi. Kenaikan harga daging biasanya disebabkan karena kondisi cost-push inflation di mana keadaan inflasi terjadi akibat dorongan biaya produksi. Cost-push inflation ini dimulai dengan adanya penurunan ketersediaan barang akibat menigkatnya biaya produksi. Biaya produksi dalam hal ini dapat berupa biaya produksi dalam bertani atau beternak untuk menghasilkan produk pertanian dan peternakan yang diinginkan. Menurut Ilham (2016), komponen biaya yang termasuk biaya tataniaga, seperti retribusi, penyusutan berat badan ternak selama transportasi, dan biaya transportasi yang tinggi untuk mendistribusikan daging juga turut meningkatkan harga daging di dalam negeri.

Sedangkan, apabila dilihat dari aspek konsumsi, konsumen selalu membutuhkan daging sapi, baik pada kelompok pendapatan tinggi hingga rendah, terutama saat menjelang hari raya keagamaan (Ilham, 2016). Namun sayangnya, permintaan yang tinggi tersebut tidak disertai dengan penawaran yang memadai sehingga mendorong kenaikan harga daging.

Biaya produksi meningkat dapat pula disebabkan karena kenaikan upah pekerja atau kenaikan ongkos produksi yang melibatkan ongkos bahan bakar, penerangan, air, serta ongkos transpor baik dalam memasarkan hasil maupun dalam mendapatkan bibit. Produsen akan menurunkan kuantitas penawarannya untuk menekan biaya produksi. Jika hal ini berlangsung lama maka akan terjadi kelangkaan barang yang akan memperparah tingkat inflasi (cost-push inflation) dikarenakan harga akan terus meningkat.

Penerangan sebagai salah satu komoditas dalam faktor 4 juga dapat memengaruhi inflasi dikarenakan dampak dari penyesuaian tarif listrik sejak awal tahun 2017 (Bank Indonesia, 2017). Penyesuaian ini dilakukan untuk konsumen dengan golongan 900 Volt Ampere (VA). Akibatnya, harga listrik di Provinsi Banten meningkat dan memengaruhi inflasi.

Faktor 5 mampu menjelaskan 4 persen dari variasi tingkat inflasi bulanan yang terjadi di Provinsi Banten pada periode penelitian. Variabel-variabel dalam faktor ini termasuk dalam kebutuhan pelengkap dari kebutuhan primer. Terpenuhinya kebutuhan primer pendidikan mendorong masyarakat ingin memenuhi unsur pendukung dari pendidikan tersebut seperti seragam, tas, sepatu, dan lain-lain. Terutama ketika memasuki tahun ajaran baru, dimana terjadi kenaikan permintaan untuk unsur pendukung pendidikan. Unsur-unsur yang dapat meningkatkan biaya pendidikan tersebut utamanya adalah uang kuliah untuk akademi dan perguruan tinggi (katadata.co.id, 2017). Kenaikan permintaan ini akan meningkatkan harga unsur pendukung pendidikan dan pada akhirnya akan mendorong tingkat inflasi di Provinsi Banten.

Begitu juga dengan makanan jadi yang merupakan pilihan lain untuk dikonsumsi dan sudah merupakan hal yang wajar untuk mengonsumsi makanan jadi mengingat Provinsi Banten bukan merupakan daerah tertinggal dan memiliki banyak usaha penyediaan akomodasi makanan dan minuman. Selain itu, kelompok bahan makanan jadi turut mengalami kenaikan harga akibat kenaikan harga makanan. Harga bahan makanan lebih rentan untuk mengalami kenaikan harga karena merupakan konsumsi sehari-hari dan sebagian besar memiliki sifat mudah rusak (perishable). Sebagai akibatnya, kenaikan harga tersebut berpengaruh terhadap harga makanan jadi yang menggunakan bahan baku tersebut. Pada akhirnya kenaikan harga pada kelompok bahan makanan dirasakan langsung oleh semua masyarakat. Kelompok masyarakat yang paling parah menanggung akibat negatifnya ini adalah masyarakat yang berpenghasilan rendah (Algifari, 2009).

Obat-obatan sebagai penunjang dari kebutuhan primer yaitu kesehatan juga menjadi bagian penting bagi masyarakat untuk mencapai terpenuhinya kebutuhan primer kesehatan. Selain itu, adanya impor obat-obatan juga turut meningkatkan harga obat-obatan di Indonesia. Oleh karena itu, perubahan harga barang-barang tersebut dapat berpengaruh terhadap besarnya tingkat inflasi yang ada di Provinsi Banten pada periode penelitian. 


\section{KESIMPULAN}

Berdasarkan analisis yang telah dilakukan, diperoleh bahwa hasil analisis faktor eksploratori, dari 35 variabel harga subkelompok yang dipilih, hanya 26 variabel yang dapat dikelompokkan ke dalam 5 faktor. Sisanya tidak masuk ke dalam faktor manapun. Dua puluh enam variabel yang terbagi ke dalam 5 faktor dapat menjelaskan variasi tingkat inflasi bulanan di Provinsi Banten periode tahun 20112017 sebanyak 34 persen. Sebesar 66 persen variasi sisanya dijelaskan oleh faktor lain yang belum masuk di dalam model. Faktor 1, 2, 3, 4, dan 5 berturut turut terdiri dari 2, 10, 4, 7, dan 3 variabel subkelompok pengeluaran. Poin terakhir bahwa penyebab inflasi, yaitu demand-pull inflation dan cost-push inflation terjadi di Provinsi Banten selama periode penelitian, yaitu dari tahun 2011-2017.

Salah satu indikator keberhasilan pemerintah dalam menjalankan roda pemerintahan, yaitu pengendalian terhadap laju pertumbuhan inflasi. Oleh karena itu, berdasarkan temuan penelitian ini maka saran atau rekomendasi, khususnya bagi Pemerintah Provinsi Banten, adalah menekan laju inflasi. Salah satu upaya yang dapat dilakukan adalah dengan menjaga stabilitas harga melalui pengendalian harga-harga di pasaran, menjaga ketersediaan stock barang kebutuhan dasar, meningkatkan intensitas operasi pasar, melakukan pengawasan terhadap distributor-distributor barang, menyiapkan kebijakan-kebijakan untuk mengantisipasi tingginya inflasi terutama pada momen-momen hari-hari besar keagamaan, dan memberi bantuan (subsidi) kepada industri-industri menengah sektor produksi bahan makan, bahan bakar, serta produksi beras. Melalui upaya ini diharapkan dapat mengendalikan angka inflasi daerah sehingga mampu menjaga kestabilan perekonomian daerah.

Selain itu, pemerintah perlu memberikan perhatian besar pada subkelompok pengeluaran yang tercakup pada faktor 2 , yaitu sandang laki-laki, barang pribadi, dan sandang lain, sandang anak-anak, padipadian, umbi-umbian, dan hasilnya, tembakau dan minuman beralkohol, jasa pendidikan, biaya tempat tinggal, ikan diawetkan, rekreasi, dan perlengkapan rumah tangga. Hal ini disebabkan subkelompok pengeluaran tersebut memberikan pengaruh paling besar terhadap tingkat inflasi di Provinsi Banten. Sebagian besar komoditas dalam faktor tersebut merupakan bahan makanan. Pemerintah sebaiknya menjaga kestabilan harga komoditas tersebut dengan tetap memerhatikan kesejahteraan petani.

\section{DAFTAR PUSTAKA}

\section{Buku}

Aswi \& Sukarna. (2006). Analisis deret waktu: Teori dan aplikasi. Cetakan pertama. Makassar: Andira Publisher.

Bank Indonesia. (2017). Kajian ekonomi dan keuangan regional Provinsi Banten November 2017. Jakarta: Bank Indonesia.

BPS. (2017a). Berita resmi statistik Januari-Desember 2017, Perkembangan harga indeks konsumen/ inflasi. Banten: Badan Pusat Statistik Provinsi Banten.

BPS. (2017b). Metodologi penghitungan indeks harga konsumen dan inflasi. Jakarta: Badan Pusat Statistik.

Gujarati, D. (2003). Basic econometrics. New York: McGraw Hill.

Johnson, R.A. \& Wichern, D.W. (2002). Applied multivariate statistical analysis. Upper Saddle River, N.J.: Prentice Hall.

Kuncoro, M. (2011). Metode kuantitatif: Teori dan aplikasi untuk bisnis dan ekonomi. Yogyakarta: UPP STIM YKPN.

Pramana, S. (2015). Multivariate data analysis using $R$. Jakarta: Sekolah Tinggi Ilmu Statistik

Santoso. (2006). Menggunakan SPSS untuk statistik non parametrik. Jakarta: PT. Elex Media Komputindo.

Sukirno, S. (2008). Teori pengantar makro ekonomi. Jakartra: Raja Grafindo Persada.

Supranto, J. (2004). Analisis multivariat: Arti dan interpretasi. Jakarta: PT. Rineka Cipta.

UNECE, ILO, IMF, OECD, Eurostat, \& ONS. (2009). Practical guide to producing consumer price indices. Geneva: United Nations.

Utari, G.A.D., S., Retni C. \& Pambudi, S. (2016). Inflasi di Indonesia: Karakteristik dan pengendaliannya. Seri Kebanksentralan No. 23. Jakarta: Bank Indonesia Institute.

\section{Jurnal dan Working Paper}

Algifari. (2009). Inflasi kelompok bahan makanan dengan Metode Box-Jenkins: Kasus Indonesia, 2006: 1-2009: 8. Jurnal Akuntansi dan Manajemen. 20(3), 175-182. 
Ardiansyah, H. (2017). Pengaruh inflasi terhadap pertumbuhan ekonomi di Indonesia. Jurnal Pendidikan Ekonomi, 5(3), 1-5.

Arini, P.S. \& Bendesa, I.K.G. (2012). Pengaruh Hari Galungan pada seasonal adjustment IHK dan penentuan komoditas utama yang mempengaruhi inflasi di Propinsi Bali: Analisis ARIMA. Jurnal Ekonomi Kuantitatif Terapan, $5(2), 79-86$.

Atmaja, A.S. (1999). Inflasi di Indonesia: Sumbersumber penyebab dan pengendaliannya. Jurnal Akuntansi dan Keuangan Universitas Kristen Petra, 1, 54-67.

Daniel, P.A. (2018). Analisis pengaruh inflasi terhadap laju pertumbuhan ekonomi di Kota Jambi. Ekonomis: Journal of Ecoomics and Business, 2(1), 131-136.

Fry, M.J. (1980). Money, interest, inflation and growth in Turkey. Journal of Monetary Economics, 6(4), 535-545.

Harjunata, Y.T. Kalalo, H.Y.T., Rotinsulu, T.O., \& Maramis, M.T.B. (2016). Analisis faktor-faktor yang mempengaruhi inflasi di Indonesia periode 2000-2014. Jurnal Berkala IImiah Efisiensi, 16(1), 706-717.

Haryani, S. \& Priantinah, D. (2018). Pengaruh inflasi, nilai tukar Rupiah/Dolar AS, tingkat suku bunga $\mathrm{BI}, \mathrm{DER}, \mathrm{ROA}, \mathrm{CR}$ dan NPM terhadap return saham. Jurnal Nominal, 7(2), 106-124.

Ilham, N. (2016). Kebijakan pengendalian harga daging sapi nasional. Jurnal Analisis Kebijakan Pertanian, 7(3), 211-221.
Kalsum, U. (2017). Pengaruh pengangguran dan inflasi terhadap pertumbuhan ekonomi di Sumatera Utara. Ekonomikawan, Jurnal IImu Ekonomi dan Pembangunan, 17(1), 87-94.

Maggi, R. \& Saraswati, B.D. (2013). Faktor-faktor yang mempengaruhi inflasi di Indonesia: Model Demand Pull Inflation. Jurnal Ekonomi Kuantitatif Terapan, 6(2), 71-77.

Panjaitan, M.N.Y. \& Wardoyo. (2016). Faktor-faktor yang mempengaruhi inflasi di Indonesia. Jurnal Ekonomi Bisnis, 21(3), 182-193.

Saputra, K. \& S.B.M., Nugroho. (2014). Faktor-faktor yang mempengaruhi inflasi di Indonesia 20072012. Diponegoro Journal of Economics, 3(1), 1-15.

\section{Majalah}

Tripena, A. (2011). Peramalan indeks harga konsumen dan inflasi Indonesia dengan Metode Arima BoxJenkins. Magistra No. 75 Th. XXIII, hal. 11.

\section{Website:}

Bank Indonesia. (2018). Disagregasi Inflasi. Diperoleh tanggal 15 Maret 2019, dari https://www.bi.go. id/id/moneter/inflasi/pengenalan/Contents/ Disagregasi.aspx.

Katadata.co.id. (2017). Biaya pendidikan naik, BPS catat inflasi September 0,13\%. Diperoleh tanggal 17 Maret 2019, dari https://katadata.co.id/ berita/2017/10/02/biaya-pendidikan-naik-bpscatat-inflasi-september-013. 
